\title{
A comprehensive theoretical view of the bonding in actinide molecular complexes
}

\author{
Laurence Petit, Laurent Joubert, Pascale Maldivi and Carlo Adamo \\ Laboratoire d'Electrochimie et de Chimie Analytique, CNRS UMR-7575, Ecole Nationale Supérieure de Chimie de \\ Paris, 11 rue Pierre et Marie Curie, F-75231 Paris Cedex 05, France \\ Laboratoire de Reconnaissance Ionique, DRFMC/LCIB (UMR_E 3 CEA-UJF), CEA-Grenoble, 17 rue des Martyrs, F- \\ 38054 Grenoble Cedex 9, France.
}

\section{SUPPORTING INFORMATION}

\section{Supporting information 1: complete references}

\section{$\underline{\text { Reference } 3}$}

Mazzanti, M.; Wietzke, R., Pécaut, J.; Latour, J-M.; Maldivi, P.; Remy, M. Inorg. Chem. 2002, 41, 2389.

\section{$\underline{\text { Reference } 14}$}

Gaussian 03, Revision C.02, Frisch, M. J.; Trucks, G. W.; Schlegel, H. B.; Scuseria, G. E.; Robb, M. A.; Cheeseman, J. R.; Montgomery, Jr., J. A.; Vreven, T.; Kudin, K. N.; Burant, J. C.; Millam, J. M.; Iyengar, S. S.; Tomasi, J.; Barone, V.; Mennucci, B.; Cossi, M.; Scalmani, G.; Rega, N.; Petersson, G. A.; Nakatsuji, H.; Hada, M.; Ehara, M.; Toyota, K.; Fukuda, R.; Hasegawa, J.; Ishida, M.; Nakajima, T.; Honda, Y.; Kitao, O.; Nakai, H.; Klene, M.; Li, X.; Knox, J. E.; Hratchian, H. P.; Cross, J. B.; Bakken, V.; Adamo, C.; Jaramillo, J.; Gomperts, R.; Stratmann, R. E.; Yazyev, O.; Austin, A. J.; Cammi, R.; Pomelli, C.; Ochterski, J. W.; Ayala, P. Y.; Morokuma, K.; Voth, G. A.; Salvador, P.; Dannenberg, J. J.; Zakrzewski, V. G.; Dapprich, S.; Daniels, A. D.; Strain, M. C.; Farkas, O.; Malick, D. K.; Rabuck, A. D.; Raghavachari, K.; Foresman, J. B.; Ortiz, J. V.; Cui, Q.; Baboul, A. G.; Clifford, S.; Cioslowski, J.; Stefanov, B. B.; Liu, G.; Liashenko, A.; Piskorz, P.; Komaromi, I.; Martin, R. L.; Fox, D. J.; Keith, T.; Al-Laham, M. A.; Peng, C. Y.; Nanayakkara, A.; Challacombe, M.; Gill, P. M. W.; Johnson, B.; Chen, W.; Wong, M. W.; Gonzalez, C.; and Pople, J. A.; Gaussian, Inc., Wallingford CT, 2004.

\section{Supporting information 2: computational details}

All calculations were performed with the Gaussian 03 package $^{1}$, while we used the Topmod suite of programs for the topological analysis. ${ }^{2}$ In agreement with previous tests, we have adopted the DFT route ${ }^{3}$ with the GGA BP86 functional. ${ }^{4}$ Each time, the metal was described by small core segmented Stuttgart pseudopotentials. ${ }^{5}$ The corresponding RECP and valence basis sets were applied for halide counterions while remaining atoms (C and $\mathrm{O})$ were treated with the 6-31G(d) basis set. All optimizations were carried with an extra fine grid for numerical integration. This method was found to ensure a correct electronic filling for open-shell systems. According to the Hund's rule in weak field, $\mathrm{Nd}(\mathrm{III})$ and U(III) formally correspond to a quartet while Am(III) features a $\mathrm{f}^{6}$ ground state. Resulting structures were characterized as minima by calculating their vibrational spectra.

Population analyses were achieved using either classical orbital approaches such as the Mulliken's distribution model $^{6}$ and a natural population analysis (NPA), ${ }^{7}$ or quantum chemical topologies (QCT). ${ }^{8-10}$ Explaining thoroughly the theoretical ground of the latter techniques is obviously beyond our scope and we refer the reader to ref. 8 to 10 for a deeper scrutiny on this topic. Even so, we would like to point out several aspects to allow an easier comprehension of our results. In the atoms in molecules (AIM) approach, ${ }^{8}$ each atom is defined as a region of the real space and consists in a bundle of electron density gradient paths attracted by a single nucleus. This natural partition of the electronic density allows the evaluation of atomic properties defined as volume integrals 
over non-overlapping atoms or topological atomic basins. In particular, the electron population associated with an atomic basin corresponds to the volume integral of the electronic charge density over this basin. ${ }^{11}$ Furthermore, the AIM theory provides solid physical grounds to the chemical bond concept. In this approach, a bond between two atoms implies the presence of a particular line linking the two nuclei. Along this line, called a bond path, the electron density is a maximum with respect to all the other neighbouring lines connecting the nuclei. Hence, information on the nature of the chemical bond can be obtained by examining the characteristics of the bond critical point (hereafter BCP). Localized on the bond path, this point corresponds to a minimum of the electron density with respect to the other points of the path. For high values of $\rho_{\mathrm{BCP}}$ with $\Delta \rho_{\mathrm{BCP}}<0$, a substantial electronic charge is concentrated in the internuclear region, thus characterizing a shared interaction (covalent or slightly polar). In contrast, a closed-shell interaction, e.g. ionic or strongly polarized interaction (our case in the study), is revealed by a low value of $\rho_{\mathrm{BC}}$ and a positive sign of its laplacian (charge depletion). Finally, a quantitative measure of the electron pair sharing between two atoms A and B can be obtained by calculating the delocalization index $\delta(\mathrm{A}, \mathrm{B})$ (see ref. 12 for details).

Another way to partition the electronic density is to analyse the topology of the electron localization function $\left(\eta(\mathbf{r})\right.$, ELF) ${ }^{9,10}$ This function corresponds, in a good approximation, to a compact form of the spin-pair composition function and provides insights into the nature of the electron charge distribution in terms of parallel and antiparallel spin-pair concentrations. ${ }^{13} \eta(\mathbf{r})$ is confined between 0 and 1 . Portions of the real space characterized by a high probability to find anti-parallel spin-pair concentrations correspond to values of $\eta(\mathbf{r})$ close to 1 . In contrast, $\eta(\mathbf{r})$ tends to 0 as the probability to find parallel spin-pair concentrations increases. During the nineties, Silvi and $\operatorname{Savin}^{10}$ proposed a gradient field topological analysis of this function, providing a quantum chemical reformulation of the empirical Lewis chemical bond model. The topology of ELF gradient field is more complex than that of AIM, presenting non atomic basins such as bonding basins, shared between two or more neighboring atoms (see reference 14 for details on the nature of these basins). In our study, we find 7 basins, 3 core $(\mathrm{C}(\mathrm{C}), \mathrm{C}(\mathrm{O})$ and $\mathrm{C}(\mathrm{M}))$ and 5 valence basins $(\mathrm{V}(\mathrm{C}), \mathrm{V}(\mathrm{O}), \mathrm{V}(\mathrm{M}), \mathrm{V}(\mathrm{C}, \mathrm{O}), \mathrm{V}(\mathrm{X}))$. In the absence of a bonding basin between $\mathrm{M}$ and $\mathrm{C}{ }^{15}$ we can define ELF an atomic charge on the metal as the difference between the metal atomic number and the sum of the ELF basin populations of the metal.

The charge transfer involved in donation and backdonation processes was assessed in two steps. The $\pi$ contribution of the metal $\mathrm{f}$ levels on the $\mathrm{C}$ and $\mathrm{O}$ basins was first considered, providing the $\mathrm{M} \rightarrow \mathrm{CO}$ backdonation. Then, the difference between this backdonation and the global basin population of the carbonyl ligand, as listed in table 1 , gives the amount of $\mathrm{CO} \rightarrow \mathrm{M}$ donation. Note that it was less straightforward to calculate donation directly from $\sigma$ contributions to AIM and ELF basins because these orbitals are delocalized over the whole complex.

\section{References}

(1) Gaussian 03, Revision C.02, Frisch, M. J.; Trucks, G. W.; Schlegel, H. B.; Scuseria, G. E.; Robb, M. A.; Cheeseman, J. R.; Montgomery, Jr., J. A.; Vreven, T.; Kudin, K. N.; Burant, J. C.; Millam, J. M.; Iyengar, S. S.; Tomasi, J.; Barone, V.; Mennucci, B.; Cossi, M.; Scalmani, G.; Rega, N.; Petersson, G. A.; Nakatsuji, H.; Hada, M.; Ehara, M.; Toyota, K.; Fukuda, R.; Hasegawa, J.; Ishida, M.; Nakajima, T.; Honda, Y.; Kitao, O.; Nakai, H.; Klene, M.; Li, X.; Knox, J. E.; Hratchian, H. P.; Cross, J. B.; Bakken, V.; Adamo, C.; Jaramillo, J.; Gomperts, R.; Stratmann, R. E.; Yazyev, O.; Austin, A. J.; Cammi, R.; Pomelli, C.; Ochterski, J. W.; Ayala, P. Y.; Morokuma, K.; Voth, G. A.; Salvador, P.; Dannenberg, J. J.; Zakrzewski, V. G.; Dapprich, S.; Daniels, A. D.; Strain, M. C.; Farkas, O.; Malick, D. K.; Rabuck, A. D.; Raghavachari, K.; Foresman, J. B.; Ortiz, J. V.; Cui, Q.; Baboul, A. G.; Clifford, S.; Cioslowski, J.; Stefanov, B. B.; Liu, G.; Liashenko, A.; Piskorz, P.; Komaromi, I.; Martin, R. L.; Fox, D. J.; Keith, T.; Al-Laham, M. A.; Peng, C. Y.; Nanayakkara, A.; Challacombe, M.; Gill, P. M. W.; Johnson, B.; Chen, W.; Wong, M. W.; Gonzalez, C.; and Pople, J. A.; Gaussian, Inc., Wallingford CT, 2004.

(2) Noury, S.; Krokidis, X.; Fuster, F.; Silvi, B.; Topmod package, Université Pierre et Marie Curie, 1997.

(3) Koch, W.; Holthausen, M. C. A Chemist's Guide to Density Functional Theory, Wiley-VCH: Weinheim, 2000.

(4) Becke, A. D. Phys. Rev. A 1988, 38, 3098 - Perdew, J. P. Phys. Rev. B 1986, 33, 8822.

(5) Cao, X.; Dolg, M. J. Mol. Struct. (Theochem) 2002, 581, 139 - Cao, X.; Dolg, M. J. Mol. Struct. 2004, 673, 203 - Dolg, M.; Stoll, H.; Savin, A.; Preuss, H. Theor. Chim. Acta 1989, 5, 173.

(6) Mulliken, R. S. J. Chem. Phys. 1955, 23, 1833. 
(7) Reed, A. E.; Weinstock, R. B.; Weinhold, F. J. Chem. Phys. 1985, 83, 735 - Foster, J. P.; Weinhold, F. J. Am. Chem. Soc. 1980, 102, 7211 - Reed, A. E.; Curtiss, L. A.; Weinhold, F. Chem. Rev. (Washington, D. C.) $1988,88,899$.

(8) Bader, R. F. Atoms in molecules : A Quantum Theory, Oxford University Press : Oxford, U. K., 1994.

(9) Becke, A. D.; Edgecombe, K. E. J. Chem. Phys. 1990, 92, 5397.

(10) Silvi, B.; Savin, A. Nature 1994, 371, 683.

(11) Bader, R. F. W.; Matta, C. F. J. Phys. Chem. A 2004, 108, 8385.

(12) Fradera, X; Austen, M. A.; Bader, R. F. W. J. Phys. Chem. A 1999, 103, 304.

(13) Silvi, B. J. Phys. Chem. A 2003, 107, 3081.

(14) Savin, A.; Silvi, B.; Colonna, F. Can. J. Chem. 1996, 74, 1088.

(15) Joubert, L.; Silvi, B.; Picard, G. Theor. Chem. Accounts 2000, 104, 109.

\section{Supporting information 3:}

Table SI1. Structural parameters (X=halide, either $\mathrm{F}^{-}$or $\left.\mathrm{I}^{-}\right)$

\begin{tabular}{|c|c|c|c|c|c|c|}
\hline Complexes, symmetry & M-C, $\AA$ & $\mathbf{M}-\mathbf{X}, \AA$ & $\mathrm{C}-\mathrm{O}, \AA$ & (X-M-C), ${ }^{\circ}$ & $(\mathrm{X}-\mathrm{M}-\mathrm{X}) \mathrm{,}^{\circ}$ & $v(\mathbf{C O}), \mathrm{cm}^{-1}$ \\
\hline Experiment & $\begin{array}{l}2.485^{1}, \\
2.383^{2}\end{array}$ & & $\begin{array}{l}1.13^{1} \\
1.142^{2}\end{array}$ & & & $\begin{array}{c}1922^{1}, 1900^{2} \\
1976^{3}\end{array}$ \\
\hline $\mathrm{CO}$ (calc.) & - & - & 1.15 & - & - & 2115 \\
\hline $\mathrm{F}_{3}-\mathrm{Nd}-\mathrm{CO}, \mathrm{C}_{3 \mathrm{v}}$ & 2.88 & 2.08 & 1.14 & 103 & 115 & 2170 \\
\hline $\mathrm{F}_{3}-\mathrm{Am}-\mathrm{CO}, \mathrm{C}_{1}$ & 2.66 & 2.08 & 1.15 & 105 & 115 & 2125 \\
\hline $\mathrm{F}_{3}-\mathrm{U}-\mathrm{CO}, \mathrm{C}_{3 \mathrm{v}}$ & 2.43 & 2.08 & 1.17 & 113 & 106 & 1964 \\
\hline $\mathrm{I}_{3}-\mathrm{Am}-\mathrm{CO}, \mathrm{C}_{3 \mathrm{v}}$ & 2.54 & 2.94 & 1.15 & 84 & 119 & 2104 \\
\hline $\mathrm{I}_{3}-\mathrm{U}-\mathrm{CO}, \mathrm{C}_{1}$ & 2.40 & 2.93 & 1.16 & 87 & 119 & 2007 \\
\hline
\end{tabular}

\section{Supporting information 4:}

Table SI2. Summary of the topological analyses (AIM and ELF) performed on $\mathrm{X}_{3} \mathrm{MCO}$ complexes. From left to right: electronic densities and their laplacian values calculated at the metal-carbon bond critical point (BCP, in a.u.) and delocalization indexes $\delta(\mathrm{M}, \mathrm{C})$ between the metal and the carbon atoms.

\begin{tabular}{|l|l|l|l|l|}
\hline & $\rho_{\text {BCP }}$ & $\Delta \rho_{\text {BCP }}$ & $\begin{array}{c}\delta(\mathbf{M}, \mathbf{C}), \\
\text { AIM }\end{array}$ & $\begin{array}{c}\delta \text { (M,C), } \\
\text { ELF }\end{array}$ \\
\hline $\mathrm{F}_{3}$-Nd-CO & 0.02 & 0.06 & 0.20 & 0.14 \\
$\mathrm{~F}_{3}-\mathrm{Am}-\mathrm{CO}$ & 0.04 & 0.13 & 0.40 & 0.32 \\
$\mathrm{~F}_{3}-\mathrm{U}-\mathrm{CO}$ & 0.07 & 0.25 & 0.94 & 0.96 \\
$\mathrm{I}_{3}-\mathrm{Am}-\mathrm{CO}$ & 0.05 & 0.16 & 0.44 & 0.36 \\
$\mathrm{I}_{3}-\mathrm{U}-\mathrm{CO}$ & 0.06 & 0.23 & 0.80 & 0.68 \\
\hline
\end{tabular}

\footnotetext{
${ }^{1}\left(\mathrm{C}_{5} \mathrm{Me}_{5}\right)_{3} \mathrm{U}(\mathrm{CO})$, Evans, W. J.; Kozimor, S. A.; Nyce, G. W.; Ziller, J. W. J. Am. Chem. Soc. 2003, 125, 13831 - IR spectrum in a KBr pellet.

${ }^{2}\left(\mathrm{C}_{5} \mathrm{Me}_{4} \mathrm{H}\right)_{3} \mathrm{U}(\mathrm{CO})$, Parry, J.; Carmona, E.; Coles, S.; Hursthouse, M. J. Am. Chem. Soc., 1995, 117, 2649 - IR spectrum in petroleum ether solution.

${ }^{3}\left(\mathrm{Me}_{3} \mathrm{SiC}_{5} \mathrm{H}_{4}\right)_{3} \mathrm{U}(\mathrm{CO})$, Brennan, J. G.; Andersen, R. A.; Robbins, J. L. J. Am. Chem. Soc. 1986, 108, 335 - IR spectrum in hydrocarbon solution.
} 